\title{
IMPLEMENTASI DAN DAMPAK E-COURT (ELECTRONICS JUSTICE SYSTEM) TERHADAP ADVOKAT DALAM PROSES PENYELESAIAN PERKARA DI PENGADILAN NEGERI SELONG
}

\author{
Baiq Paridah \\ Fakultas Hukum Universitas Gunung Rinjani \\ e-Mail : baiqparidah@gmail.com
}

\section{Info Artikel}

Sejarah Artikel :

Diterima Juni 2020

Disetujui Oktober 2020

Publikasi November 2020

\section{Keyword:}

application of e-court, advocates, Selong District Court

\section{Alustract}

This thesis aims to determine how the impact on the application of the e-court application on advocates in the process of solving cases in the Selong district court, as well as to fine out what are the obstacles to the application of the ecourt application. The benefits of this research are expected to provide knowledge about e-court and the steps in -ecourt operation with the principle of simple, fast and low cost. The research method used is empirical normative legal research methods. The results of this study indicate that the stipulation of perma no.3 of 2018 jo perma no 1 of 2019 concerning the administration of cases and trials in court electronically shows quite good results and can be applied by all lawyers.

\section{Ahstrak}

Penelitian ini bertujuan untuk mengetahui bagaimana dampak terhadap penerapan aplikasi $e$-court, terhadap advokat dalam proses penyelesaian perkara di Pengadilan Negeri Selong, serta untuk mengetahui apa saja kendala terhadap penerapan aplikasi e-court. Manfaat penelitian ini diharapkan dapat memberikan pengetahuan mengenai e-court dan langkahlangkah dalam pengoperasian e-court dengan asas sederhana, cepat dan biaya ringan. Metode penelitian yang digunakan adalah Metode penelitian Hukum Normatif empiris. Hasil penelitian ini menunjukkan bahwa penerapan Perma no.3 tahun 2018 Jo. Perma No.1 tahun 2019 tentang Administrasi Perkara dan Persidangan di Pengadilan Secara Elektronik menunjukkan hasil yang cukup baik dan dapat diterapkan oleh semua advokat. 


\section{A. PEndahuluan}

Mahkamah Agung telah menetapkan visi dan misi ${ }^{1}$ dan akan dicapai dalam waktu 25 (dua puluh lima) tahun yang akan datang. "Mewujudkan Badan Peradilan yang Agung" merupakan visi Mahkamah Agung yang akan menjadi arah serta tujuan untuk semua pengembangan program dan kegiatan yang akan dilaksanakan di wilayah-wilayah fungsi khusus dan fungsi pendukung serta fungsi akuntabilitas, persiapan kurun waktu Lembaga Peradilan Indonesia, yang disebut Cetak Biru (Blue Print) merupakan penyempurnaan Peradilan Indonesia 20102035. Cetak Biru adalah versi dari tahun 2003, untuk lebih menfokuskan arah dan sasaran agar sampai pada cita-cita pembaharuan badan peradilan secara utuh. Cetak Biru Pembaharuan Pengadilan 20102035 berisi ancang-ancang strategis untuk 25 (dua puluh lima tahun) yang akan datang dengan dimaksudkan untuk lebih memfokuskan arah dan sasaran untuk mencapai tekad pembaharuan badan peradilan secara komplit.

Mahkamah Agung Republik Indonesia dengan keanekaragaman programnya sudah berusaha agar dapat Memakai teknologi untuk pengelolaan informasi yang dibutuhkan internal organisasi maupun para pencari keadilan khususnya advokat maupun pengguna pengadilan. Akan tetapi, karena adanya perubahan keperluan, sampai saat ini, masih banyak muncul keluhan dari para pencari keadilan terutama advokat. Di lain sisi, dalam lembaga Mahkamah Agung Republik Indonesia serta lembaga-lembaga peradilan yang berada dibawahnya juga masih bisa merasakan manfaat dari suatu program sistem pengelolaan teknologi dan informasi yang komprehensif dan terintegrasi, supaya mempermudah serta mempersingkat cara melakukan tugas serta fungsi di masing-masing unit kerja, sehingga

1 Mahkamah Agung RI, Cetak Biru Pembaharuan Peradilan 2010-2035, (Jakarta.2010) hal.14. dapat diharapkan adanya peningkatan kualitas pelayanan informasi untuk masyarakat.

Agar terwujudnya arsitektur ideal di atas, tahapan mengembangkan teknologi serta informasi di Mahkamah Agung Republik Indonesia dan lembaga peradilan dibawahnya dalam waktu 25 (dua puluh lima) tahun ke depan akan di bagi menjadi 3 (tiga) tahap, yaitu ${ }^{2}$ :

1. Tahap I, selama 5 (lima) tahun pertama. Sasarannya yaitu optimalisasi investasi Teknologi dan Informasi yang sudah tersedia, integrasi data serta informasi, dan penyiapan regulasi serta perubahan kultur kerja dalam rangka menyambut era bekerja berbasis teknologi dan informasi.

2. Tahap II, selama 10 (sepuluh) tahun kedua. Sasarannya yaitu terciptanya sistem informasi yang konsisten bagi seluruh lembaga peradilan sehingga memungkinkan pemanfaatan data serta informasi untuk menjaga kesatuan hukum serta membuka peluang untuk peningkatan akses terhadap layanan pengadilan.

3. Tahap III, selama 10 (sepuluh) tahun ketiga. Sasarannya yaitu diintegrasikannya proses peradilan dengan para pemangku kepentingan lainnya, termasuk para penegak hukum lain, dalam rangka menuju sistem pelayanan hukum terpadu (integrated justice system).

Keharusan penyelenggaraan semua kegiatan publik dengan transparan diatur pada Undang-Undang Nomor 14 Tahun 2008 tentang Keterbukaan Informasi Publik. Namun Sebelumnya, Mahkamah Agung Republik Indonesia sudah mulai melakukan keterbukaan peradilan untuk merealisasikan mandat Cetak Biru pada tahun 2003 dengan di keluarkannya Surat Keputusan Ketua 
Mahkamah Agung Republik Indonesia Nomor 144 Tahun 2007 tentang Keterbukaan Informasi di Pengadilan. Disamping itu, Mahkamah Agung juga mengeluarkan Surat Keputusan Wakil Ketua Mahkamah Agung Republik Indonesia Nomor 01 Tahun 2009 tentang Pedoman Pelaksanaan Pelayanan Informasi di Mahkamah Agung Republik Indonesia. Akan tetapi, penyelenggaraan kedua-duanya ternyata tengah mengalami berbagai macam kendala sehingga tidak berjalan optimal ${ }^{3}$.

Pada dasarnya, program transparansi dengan jalan penyediaan jaringan berita Pengadilan diperuntukkan untuk mencapai dua hal, yaitu:

1. menyediakan kebutuhan masyarakat pencari keadilan; dan

2. menciptakan akuntabilitas badan peradilan dalam rangka meningkatkan keyakinan masyarakat.

Upaya transparansi di lingkungan dibawah Mahkamah Agung Republik Indonesia sebenarnya sudah dimulai sejak tahun 2003 seiring dengan Program Reformasi Birokrasi, kemudian semakin menguat dengan legitimasi Surat Keputusan Mahkamah Agung Nomor 144/SK/KMA/2007, bulan Agustus 2007 tentang Keterbukaan Informasi di Pengadilan, Surat Keputusan Mahkamah Agung inilah yang kemudian menjadi sebab bagi keempat badan peradilan di lingkungan Mahkamah Agung agar memberikan pelayanan kepada publik, Surat Keputusan Mahkamah Agung ini kemudian diperbaharui menjadi Surat Keputusan Mahkamah Agung Nomor 1144/KMA/SK/I/2011 tanggal 5 Januari 2011 tentang Pedoman Pelayanan Informasi di Pengadilan. ${ }^{4}$

3 Ibid, hal.78

4 Edi Hudiata, Modernisasi Peradilan Melalui UU KIP Nomor 14 Tahun 2008 dan SK KMA Nomor 1144/KMA/SK/I/2011, Majalah Hukum Varia Peradilan Tahun XXVII, No.320 Juli 2012, hal.114
Sesuai Bab III Pasal 6 Keputusan KMA Nomor 144/SK/KMA/2007, siapapun berhak mendapatkan informasi berupa gambaran umum pengadilan, gambaran umum proses beracara, hak-hak pencari keadilan, biaya perkara, putusan pengadilan, agenda sidang, mekanisme pengaduan dugaan pelanggaran yang dilakukan Hakim dan Pegawai, serta hak masyarakat dan tata cara mendapatkan informasi. Sejak lauching informasi Desk (Meja Informasi) pada awal April 2009 di Mahkamah Agung, dengan harapan bisa meningkatkan Client Service atau pelayanan publik, akan dapat dirasakan hasilnya yaitu sangat berdampak terhadap peningkatan citra lembaga peradilan. Dengan orientasi peningkatan pelayanan publik, saat ini sebagian besar Pengadilan Tingkat Pertama dan Banding yang telah menyediakan fasilitas Informasi Desk dan berfungsi untuk One Stop Service atau pelayanan satu titik, hal tersebut mempermudah bagi masyarakat pencari keadilan. $^{5}$

Kebudayaan penduduk global telah menjalani perubahan secara signifikan. Hal ini ditandai dengan datangnya arus besar pekembangan ilmu pengetahuan dan teknologi, khususnya teknologi informatika, yakni teknologi yang berbasis computer serta telekomunikasi ke seluruh penjuru dunia. Dampaknya yaitu dunia berubah menjadi wilayah yang semula terasa begitu besar serta luas menjadi terasa semakin sempit, tanpa terkecuali. Perkembangan teknologi juga mempengaruhi dunia peradilan di Indonesia, sebagaimana sistem peradilan di Indonesia berjalan dengan pesat karena adanya perkembangan teknologi informasi ini. $^{6}$

Pemakaian teknologi informasi dengan sistem peradilan modern sebenarnya merupakan salah satu ciri lembaga yang disebut excellent, yaitu manajemen dan

Ibid.hlm.116.

6 Dr.Abdullah, Era Baru Peradilan Berbasis Teknologi Informasi, Starlita Dasuki (Ed), Majalah Mahkamah Agung Edisi XVII/2018, hlm.3. 
kepemimpinan peradilan sebagai "driver" lembaga peradilan, sehingga mempermudah dalam implementasi kebijakan-kebijakan yang berkaitan dengan sumber daya manusia, sumber daya material, sumber daya finansial serta proses peradilannya. Harapan dari hasil peradilan yang excellent adalah terpenuhinya kebutuhan dan kepuasan khususnya para advokad untuk berproses di pengadilan, keterjangkauan serta mudah diaksesnya keterbukaan sehingga menimbulkan kepercayaan publik akan lembaga peradilan tersebut.

Ketua Mahkamah Agung Prof. DR. M. Hatta Ali, S.H., M.H., meluncurkan secara resmi penggunaan aplikasi e-court yang berada di Balikpapan, Kalimantan Timur, pada hari Jum'at, tanggal 13 Juli tahun 2018. Dalam kesempatan tersebut, Ketua Mahkamah Agung Republik Indonesia secara simbolis menggunakan aplikasi e-court, menurut Ketua Mahkamah Agung, tingkat pelayanan lembaga peradilan di Indonesia memang masih belum setaraf dengan pengadilan pengadilan di negara-negara yang sudah maju budaya hukum dan peradilannya, akan tetapi dengan pelayanan melalui e-court tersebut Mahkamah Agung optimis bergerak kearah perubahan yang memungkinkan pelayanan peradilan di Indonesia semakin mendekati standar peradilan secara internasional, karena wibawa lembaga peradilan sangat dipengaruhi oleh kecepatan dalam memberikan layanan yang dibutuhkan oleh masyarakat terutama advokad serta keterbukaan informasi yang diberikan oleh lembaga peradilan. Mahkamah Agung terus mendorong usaha optimalisasi dengan penggunaan teknologi informasi dalam mendukung pelayanan, transparansi serta akuntabiliti terkait dengan Peraturan Mahkamah Agung Nomor 3 Tahun 2018 tentang administrasi perkara secara elektronik di pengadilan, sehingga sangat diharapkan akan adanya peningkatan pada parameter penegakan kontrak, khususnya dalam sub-parameter Indeks Kualitas Proses
Berperkara, di mana pada poin otomatis perkara bisa di peroleh tambahan melalui indikator e-Filing, e-Payment dan eSummons. ${ }^{7}$

Dengan diterapkannya aplikasi e-court lembaga peradilan mengalami perubahan dalam penanganan prosedur berperkara seperti dapat mengefisiensi waktu, perubahan lingkungan dalam proses berinteraksi dengan aparatur pengadilan yang maksudnya bahwa dapat meminimalisir para pihak yang berperkara untuk hadir langsung ke pengadilan, dan memudahkan masyarakat yang utamanya dalam mencari keadilan terutaama advokat untuk mendapatkan informasi dan pengetahuan. Sehingga pemanfaatannya sangat di rasakan oleh para advokat itu sendiri, terutama mengenai :

1. Mengirit waktu dan biaya dalam proses pembayaran.

2. Pembayaran biaya panjar perkara dilakukan dengan virtual account yang dapat di bayarkan melalui bank secara elektronik, dan

3. Surat-surat dapat disimpan secara baik dan di akses dari berbagai lokasi dan media.

Setelah Mahkamah Agung menerbitkan peraturan Mahkamah Agung Nomor 3 Tahun 2018 tentang Administrasi Perkara di Pengadilan Secara Elektronik merupakan tindakan yang dilakukan untuk memenuhi asas peradilan yaitu sederhana, cepat dan biaya ringan. Dengan sistem pelayanan online tersebut, maka diharapkan ruang interaksi langsung antara advokat dan pegawai pengadilan dapat dipersempit, yang pada dasarnya e-court merupakan layanan bagi pengguna terdaftar khususnya advokad untuk mendaftarkan perkara secara online, mendapatkan taksiran panjar biaya perkara secara online, sehingga yang termasuk dalam e-court tersebut ada tiga fitur utama dari payung hukum berupa pendaftaran perkara

\footnotetext{
7 Ibid. hlm.4
} 
(e-filing), dan pembayaran panjar uang perkara (e-payment) serta penyampaian pemberitahuan dan pemanggilan persidangan secara elektronik (e-summons). ${ }^{8}$

Pengguna aplikasi tersebut hanya diberi status terdaftar apabila dapat diverifikasi oleh pengadilan tinggi. Pengguna terdaftar patuh pada syarat dan ketentuan yang berlaku, dalam hal pendaftaran secara online yang pada saat ini hanya dikhususkan untuk advokat, pengguna terdaftar harus setelah mendaftar dan mendapatkan akun, harus melalui mekanisme validasi advokat oleh Pengadilan Tinggi tempat di mana advokat di sumpah, sedangkan pendaftaran oleh perseorangan atau badan hukum akan diatur lebih lanjut. Pelanggaran pada syarat tersebut akan mendapatkan teguran, penghentian hak akses serta penghentian hak akses permanen. Lingkup administrasi $e-$ court hanya berlaku untuk perkara perdata, agama, tata usaha militer dan tata usaha negara.

Para pengacara atau advokat yang merupakan salah satu unsur penting dalam dunia peradilan tidak termasuk pengecualian dari berlakuknya Peraturan Mahkamah Agung (PERMA) Nomor 3 Tahun 2018, terkait dengan itulah para advokat diharuskan menggunakan aplikasi tersebut dalam beracara, untuk mengatasi kesenjangan itulah maka dilakukan sosialisasi mengenai $e$ court serta adanya brosur mengenai e-court pada peradilan tingkat pertama, khususnya pada Pengadilan Negeri Selong yang sudah melakukan sosialisasi tentang e-court kepada para advokat, tujuannya untuk memberikan pembelajaran dan pemahaman serta penegasan terhadap para advokat bahwa di Pengadilan Negeri Selong akan diberlakukannya pendaftaran perkara gugatan, bantahan serta permohonan dengan sistem e-court, maka dengan diberlakukannya pendaftaran perkara melalui

\footnotetext{
8 Rita Zahara, E-court Lompatan Besar Dalam Pelayanan Perkara, Majalah Mahkamah Agung Edisi XVII/2018, hlm.11.
}

e-court, sampai dengan bulan Juli 2020 Pengadilan Negeri Selong telah menerima pendaftaran perkara gugatan biasa sebanyak 82 perkara, gugatan sederhana sebanyak 13 perkara dan permohonan sebanyak 87 , hal tersebut menandakan bahwa pendaftaran dengan sistem e-court tersebut memberikan kemudahan dalam pendaftaran perkara khususnya bagi para advokat, karena sebagian besar perkara yang didaftarkan oleh para advokat sebagai pengguna e-court memilih untuk mendaftarkan perkaranya tanpa harus datang ke Kantor Pengadilan Negeri Selong.

Berdasarkan uraian tersebut di atas, penulis tertarik untuk melaklukan penelitian tentang implementasi dan dampak e-court (electronics justice system) terhadap advokat dalam proses penyelesaian perkara di Pengadilan Negeri Selong. Adapun rumusan masalahnya adalah Pertama, bagaimana mekanisme beracara dengan e-court (electronics justice system) dalam penyelesaian perkara di Pengadilan. Bagaimana dampak terhadap advokat dalam pelaksanaan sistem e-court (electronics justice system) dalam penyelesaian perkara di Pengadilan Negeri Selong.

\section{B. METODELOGI PENELITIAN}

Tipe Penelitian ini adalah gabungan dari penelitian hukum normatif dan empiris ${ }^{9}$ dan bersifat deskritif. Dengan demikian data yang dibutuhkan dalam penelitian akan mencakup data primer dan data sekunder. Data primer merupakan data yang diperoleh langsung dari objek yang diteliti ${ }^{10}$ berupa informasi langsung yang diperoleh dari lapangan melalui kuesioner dan wawancara kepada responden yang terdiri dari Pengadilan Negeri, Pengadilan Tinggi, Mahkamah Agung,

9 Soerjono Soekanto dan Sri Mamudji, Penelitian Hukum Normatif : Suatu Tinjauan Singkat, Edisi 1, Cet V,Jakarta : PT Taja Grafindo Persada , 2001, hal 12-14

${ }^{10}$ Rianto Adi, Metodologi Penelitian Sosial dan Hukum, Jakarta: Granit,2004, hal 57.jo. Soerjono

Soekanto, Pengantar Penelitian Hukum .Jakarta: UI Press, 1986 hal 12. 
Hakim, Advokat dan Pakar Hukum dari Perguruan Tinggi. Data sekunder di bidang hukum dapat dibedakan menjadi bahan hukum yang meliputi : (a). Bahan hukum primer yaitu bahan hukum yang bersifat mengikat berupa peraturan perundangundangan terkait pengaturan tentang $e$ court, advokat dan pelayanan publik; (b). Bahan hukum sekunder yang memberikan penjelasan mengenai bahan hukum primer seperti berbagai kepustakaan hukum (Hasil penelitian/ karya ilmiah, majalah/jurnal hukum atau artikel terkait materi peradilan); dan c. Bahan hukum tersier yang memberikan penjelasan / petunjuk (kamus dan informasi tentang peradilan).

Pengumpulan data dilakukan dengan cara inventarisasi dan mempelajari data kepustakaan berupa peraturan perundangundangan, buku-buku literature, jurnaljurnal, majalah, Koran, internet dan informasi nara sumber. Analisis data dalam penelitian ini akan menggunakan analisis kualitatif baik terhadap data primer maupun sekunder.

\section{PEMBAHASAN}

1. Mekanisme beracara dengan ecourt (electronics justice system) dalam penyelesaian perkara di Pengadilan Negeri Selong

E-court adalah sebuah instrument Pengadilan yang merupakan bentuk pelayanan terhadap masyarakat dalam hal pendaftaran perkara secara online. ${ }^{11}$ Sesuai dengan ketentuan Peraturan Mahkamah Agung Nomor 3 Tahun 2018 tentang Administrasi perkara di Pengadilan Secara Elektronik, perlu disempurnakan terutama yang menyangkut tata cara persidangan secara elektronik, sehingga atas dasar tersebut lembaga Mahkamah Agung Republik Indonesia mengeluarkan Peraturan Mahkamah Agung Nomor 1 Tahun 2019

11 Mahkamah Agung Republik Indonesia, Buku Panduan e-Court (The Electronic Justice System), Jakarta 2019, (online).(di akses tanggal 27 Maret 2020), hlm.4 tentang Administrasi perkara dan persidangan di Pengadilan Secara Elektronik.

Penggunaan e-court perkara diharapkan bisa meningkatkan pelayanan dalam fungsinya yaitu menerima pendaftaran perkara secara online dimana masyarakat akan dapat menghemat waktu dan biaya saat melakukan pencatatan dalam berperkara. Ruang Lingkup aplikasi e-Court adalah sebagai berikut : ${ }^{12}$

a. Pendaftaran Perkara Online (E-Filing)

Pencatatan Perkara Online dalam aplikasi e-Court untuk saat ini baru dibuka jenis pendaftaran untuk perkara gugatan, bantahan, gugatan sederhana, dan permohonan. Pendaftaran Perkara ini adalah jenis perkara yang didaftarkan di Peradilan Umum, Peradilan Agama dan Peradilan TUN yang dalam pendaftarannya memerlukan effort atau usaha yang lebih, dan ini merupakan alasan untuk membuat $e$-court salah satunya adalah kemudahan berusaha.

Kuntungan Pendaftaran Perkara secara online melalui Aplikasi e-Court yang bisa diperoleh dari aplikasi ini adalah :

1) Menghemat Waktu dan Biaya dalam proses pendaftaran perkara.

2) Pembayaran Biaya Panjar yang dapat dilakukan dalam saluran multi chanel atau dari berbagai metode pembayaran dan bank.

3) Dokumen terarsip secara baik dan dapat diakses dari berbagai lokasi dan media.

4) Proses Temu Kembali Data yang lebih cepat.

b. Pembayaran panjar biaya online (ePayment)

Dalam pendaftaran perkara, pengguna terdaftar yang khusus advokat akan langsung mendapatkan SKUM yang digenerate secara elektronik oleh aplikasi e-Court. Dalam proses generate tersebut 
sudah akan dihitung berdasarkan Komponen Biaya apa saja yang sudah ditetapkan dan dikonfigurasi oleh Pengadilan, dan besaran biaya radius yang juga ditetapkan oleh Ketua Pengadilan sehingga perhitungan taksiran biaya panjar sudah diperhitungkan sedemikian rupa dan menghasilkan elektronik SKUM atau eSKUM. Pengguna terdaftar sesudah mendapatkan taksiran panjar atau eSKUM akan mendapatkan Nomor Pembayaran (Virtual Account) sebagai rekening virtual untuk pembayaran biaya panjar perkara.

c. Pemanggilan Elektronik (e-Summons).

Sesuai dengan Perma Nomor 3 Tahun 2018 bahwa Pemanggilan yang pendaftarannya dilakukan dengan menggunakan e-Court, maka bagi Pengguna Terdaftar khususnya advokat akan dilakukan secara elektronik kemudian dikirim ke alamat domisili elektronik pengguna terdaftar. Namun untuk pihak tergugat, pemanggilan pertama dilakukan dengan manual dan pada saat tergugat hadir pada persidangan yang pertama akan diminta persetujuannya apakah bersedia dipanggilan secara elektronik atau tidak, jika bersedia maka pihak tergugat akan dipanggil secara elektronik sesuai dengan domisili elektronik yang diberikan dan apabila tidak bersedia pemanggilan dilakukan secara manual seperti biasa.

d. Persidangan Elektronik (e-Litigasi)

Aplikasi e-Court juga mendukung dalam hal persidangan secara elektronik sehingga dapat dilakukan pengiriman dokumen persidangan seperti replik, duplik, kesimpulan dan atau jawaban secara elektronik yang dapat diakses oleh pengadilan dan para pihak.

Sebelum melakukan pendaftaran perkara secara online yang dilakukan oleh Advokat sebagai pengguna terdaftar, terlebih dahulu diwajibkan untuk memiliki email di aplikasi $e$ -
Court. Untuk melakukan pendaftaran melalui e-Court, yang pertama kali dilakukan adalah membuka website e-Court Mahkamah Agung di laman https://ecourt.mahkamahagung.go.id dan selanjutnya meregister Pengguna Terdaftar tersebut dengan cara memasukkan tempat tinggal email yang valid karena aktivasi akun akan dikirimkan melalui email yang didaftarkan, nantinya akan menjadi alamat domisili elektronik pengguna terdaftar, selanjutnya apabila pendaftaran berhasil pengguna terdaftar akan mendapatkan email user dan password yang telah dibuat oleh pengguna terdaftar biar login pada aplikasi $e$ Court. Setelah berhasil login untuk yang pertama kalinya pengguna terdaftar harus melengkapi data pribadi Advokat. Pemakai terdaftar untuk saat ini bisa dilakukan oleh advokat, tetapi untuk pengguna terdaftar lain dari perseorangan, pemerintah atau badan hukum sudah bisa juga mengakses e-Court dengan melakukan pendaftaran dengan datang ke pengadilan atau admin e-Court Pengadilan. Untuk mencukupi data advokat juga harus melengkapi data dokumen advokat sesuai persyaratan yang telah diatur pada Perma No. 3 Tahun 2018 yaitu KTP, Berita Acara Sumpah dan Kartu Tanda Anggota (KTA) sebagai Advokat. Dengan memenuhi data advokat yang benar untuk pendaftaran akun pengguna yang telah selesai dilakukan, akan tetapi untuk bisa beracara pada Pengadilan dengan menggunakan e-Court harus menunggu verifikasi dan validasi oleh Pengadilan Tingkat Banding, dimana Advokat tersebut disumpah. ${ }^{13}$

Pada dashboard e-Court bermuatan menu yang lebih informatif dan merupakan suatu informasi yang diberikan kepada pengguna terdaftar. Dalam dashboard tersebut terdapat kolom yang berisi informasi mengenai keadaan data perkara yang telah

13 Mahkamah Agung Republik Indonesia, Buku Panduan e-Court (The Electronic Justice System), Jakarta 2019. hlm.6-8, (diakses tanggal 20 Nopember 2019). 
didaftarkan oleh Pengguna Terdaftar melalui e-Court, diantaranya : 1). Info Perkara Gugatan; 2). Info Perkara Bantahan; 3). Info Gugatan Sederhana; dan 4). Info Perkara Pendaftaran Permohonan.

Masing-masing mempunyai info sendiri seperti acara yang berhasil mendapatkan nomor, pendaftaran sudah dibayar, pendaftaran belum dibayar, dan total dari keseluruhan perkara, sehingga bisa dijadikan pengingat bagi Pengguna Terdaftar tentang perkara yang telah didaftarkan.

Setelah pengguna terdaftar berhasil terverifikasi dan valid sebagai advokat oleh Pengadilan Tingkat Banding dimana advokat tersebut disumpah, selanjutnya adalah Tahapan Pendaftaran Perkara melalui e-Court adalah sebagai berikut : Pengguna terpilih (pengacara) memilih menu dari Pendaftaran Perkara dan memilih sesuai dengan kebutuhan jenis perkara yaitu Gugatan Online, Bantahan Online, Gugatan Sederhana Online, dan Permohonan Online. Apabila advokat sudah memilih jenis perkara yang didaftarkan maka selanjutnya pilih Tambah Gugatan, Pada Dashboard bagian Pendaftaran terdapat filter pemisahan status pembayaran yaitu status Sudah Dibayar, Belum Dibayar dan Kadaluarsa, sehingga memudahkan Pengguna untuk melihat status perkaranya. ${ }^{14}$

Ketika pengguna ingin menambakan perkara sesuai dengan jenisnya, pengguna memilih pengadilan tujuan untuk mendaftarkan perkaranya. Dalam tahapan awal, setelah memilih Pengadilan pengguna terdaftar akan mendapatkan Nomor pendaftaran Online dan Barcode akan tetapi bukan Nomor Perkara, Setelah memahami dan menyetujui syarat dan ketentuan dalam pendaftaran online melalui e-Court, tekan Tombol Daftar. Pencatatan Surat Kuasa adalah bagian dari tahapan dimana Advokat atau Pengguna terdaftar harus mengupload

\footnotetext{
14 Ibid, hlm.9-11
}

Surat Kuasa sebelum melanjutkan pendaftaran perkara.

Syarat Pendaftaran Lain dalam beracara seperti Berita Acara Sumpah, KTP dan Kartu Anggota Advokat tidak perlu dicantumkan lagi karena sudah dan selalu terlampirkan di setiap pendaftaran perkara. Dokumen seperti Berita Acara Sumpah, KTP dan KTA sudah didaftar saat pendaftaran akun pengguna terdaftar.

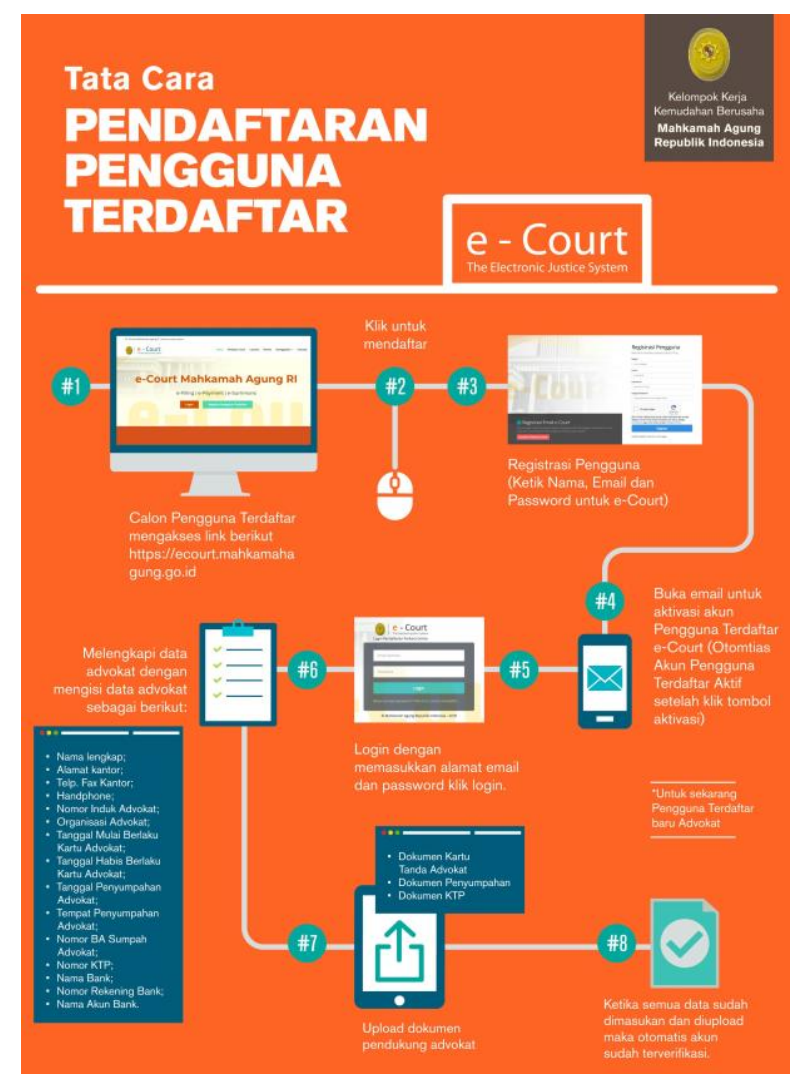

Gambar 1 : Alur Pendaftaran Akun Pengguna Terdaftar

Mengisi Data Pihak adalah menjadi hal wajib dalam pendaftaran perkara serta dalam pengisian data pihak ini akan mengisi alamat pihak, baik penggugat, tergugat, dan turut tergugat sehingga dapat memilih lokasi Provinsi, Kabupaten dan Kecamatan. Dengan melengkapi data alamat maka biaya panjar dapat ditaksirkan sesuai besaran radius masing-masing wilayah pengadilan sesuai ketetapan Ketua Pengadilan Negeri Selong. Pengguna selanjutnya menambahkan data pihak yang berperkara yaitu Penggugat, Tergugat dan Turut Tergugat (jika ada).

Tahapan berikutnya adalah melengkapi Dokumen Gugatan yang harus diupload pada 
tahapan upload Berkas. Berkas Gugatan, Persetujuan Prinsipal, dan Bukti Awal di upload dalam tahapan upload Berkas Gugatan. Ketika pengguna melakukan upload dokumen, jenis dokumen terdapat dua pilihan yaitu $p d f$ dan $d o c / r t f$, serta selain itu terdapat form template Persetujuan Prinsipal yang berarti menyatakan setuju dan bersedia beracara secara elektronik. Untuk bukti awal, bukti yang diupload berbentuk PDF dan bila bukti tersebut lebih dari satu file, maka bukti tersebut dapat di rar atau zip-kan. ${ }^{15}$
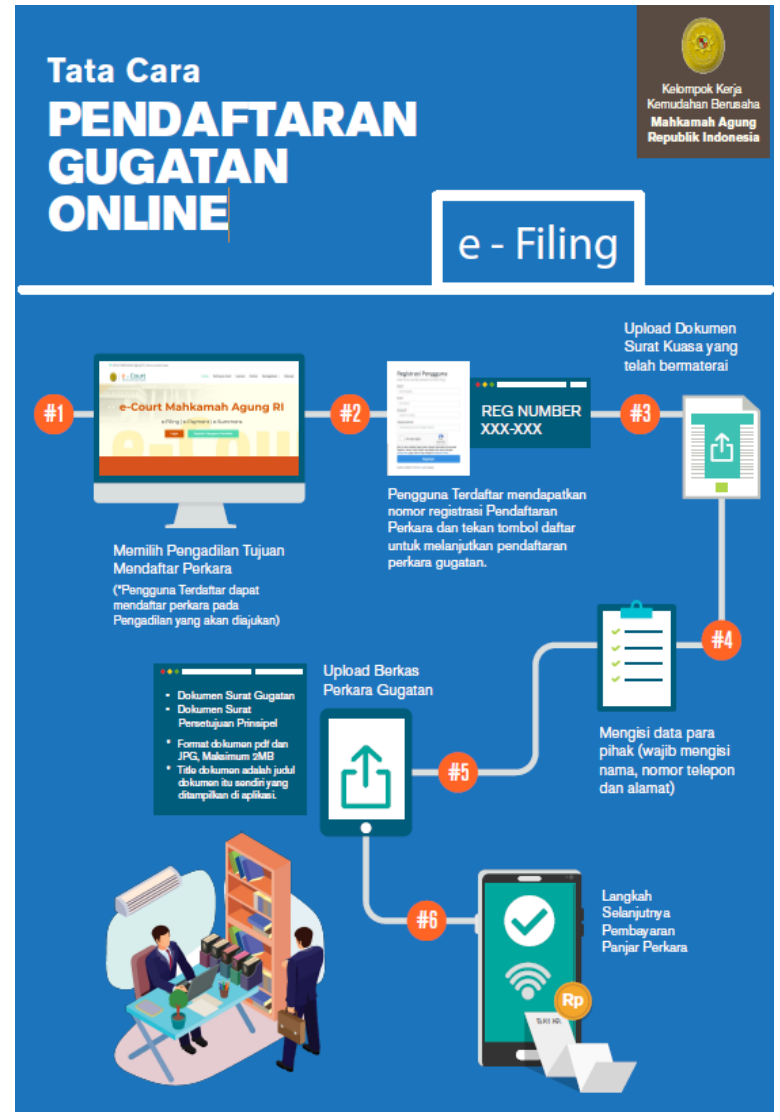

Gambar 2 : Alur Pendaftaran Online

Apabila semua data terpenuhi maka pendaftaran dan dokumen Pengguna Terdaftar akan mendapatkan taksiran panjar biaya perkara dalam bentuk Elektronik SKUM (eSKUM) yang digenerate otomatis oleh sistem dengan Komponen Biaya Panjar dan Radius yang telah ditetapkan oleh Ketua Pengadilan Negeri Selong. Besaran Taksiran Panjar Biaya Perkara ini sudah diperhitungan dengan rumusan sesuai Penentuan Taksiran

${ }^{15} \mathrm{lbid}, \mathrm{hlm} .12-15$
Biaya Panjar untuk perkara Gugatan, namun demikian apabila dalam perjalanannya terdapat kekurangan maka akan diinformasikan tagihan untuk Tambahan Biaya Panjar dan sebaliknya apabila biaya panjar kelebihan akan dikembalikan kepada Pihak yang mendaftarkan perkara.

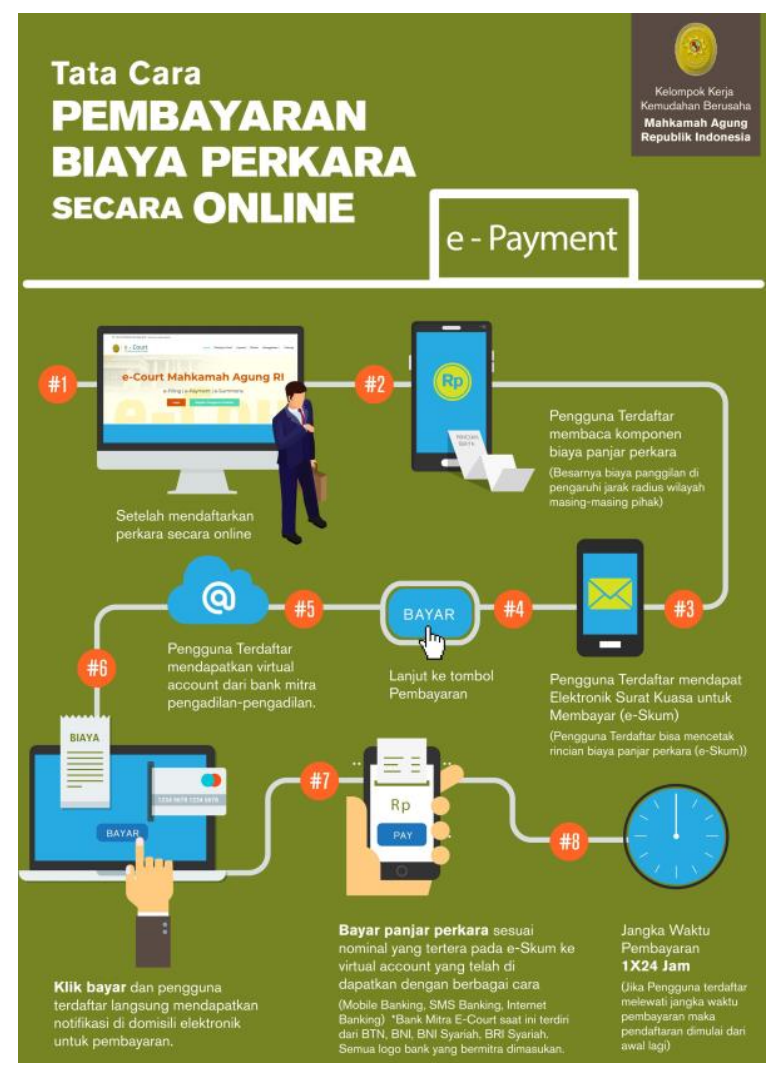

Gambar 3 : Alur Pembayaran Biaya Perkara Secara Online

Ketika Pengguna telah mendapatkan eSKUM untuk melakukan pembayarannya, selanjutnya user memilih tombol 'Lanjut Pembayaran'. Pengguna Terdaftar setelah mendapatkan Taksiran Panjar atau e-SKUM akan mendapatkan Nomor Pembayaran (Virtual Account) sebagai rekening virtual untuk pembayaran Biaya Panjar Perkara. Ketika user sudah mendapatkan nomor Virtual Account dari perkara yang telah didaftarkan, maka pemberitahuan tersebut akan masuk kedalam email yang didaftarkan sebelumnya. Email Pemberitahuan bahwa status pendaftaran, dan email tagihan serta besaran biaya panjar yang harus dibayarkan. ${ }^{16}$ Apabila sudah melakukan 
pembayaran otomatis status dari pendaftaran akan berubah. Untuk tahapan pendaftaran perkara sudah selesai berikutnya yaitu Pengguna Terdaftar menunggu verifikasi dan validasi yang dilakukan oleh Pengadilan untuk Memperoleh Nomor Perkara. Pengadilan baru akan mendapatkan notifikasi atau pemberitahuan disaat Pendaftaran Perkara sudah dilakukan pembayaran kemudian Pengadilan akan melakukan verifikasi dan validasi dilanjutkan dengan mendaftarkan Perkara di SIPP (Sistem Informasi Penelusuran Perkara) yang merupakan aplikasi manajemen administrasi perkara di Pengadilan sehingga akan otomatis mendapatkan Nomor Perkara dan melalui SIPP akan otomatis mengirimkan informasi pendaftaran perkara berhasil melalui e-Court dan SIPP.

Apabila Pengadilan telah selesai
memverifikasi
mendapatkan Nomor Perkara maka halaman verifikasi akan berubah sebagai berikut : Dengan mendapatkan Nomor Perkara Tahapan Pendaftaran Perkara Online Telah Selesai, dan menunggu pemanggilan dari Pengadilan. Pendaftaran Berhasil ini juga akan mendapatkan email pemberitahuan sehingga diharapkan informasinya cepat sampai kepada Pengguna Terdaftar. Apabila pengguna sudah melakukan pembayaran dan mendapat nomor perkara dari yang telah didaftarkan tersebut maka akan mendapat sebuah panggilan persidangan yang dikirim oleh pihak pengadilan tempat pendaftaran perkara. Apabila pengguna sudah mendapatkan panggilan elektronik selanjutnya dilakukan persidangan elektronik.

Dalam persidangan pihak penggugat dan tergugat telah setuju melakukan persidangan elektronik dengan mengisi persetujuan principal, maka para pihak dapat melakukannya sesuai dengan e-Summons yang telah dikirimkan. Pada e-Litigasi ini acara persidangan secara Elektronik oleh para pihak dimulai dari acara Jawaban, Replik, Duplik dan Kesimpulan. Untuk jadwal persidangan sudah terintegrasi dengan Tundaan Sidang di SIPP. Dokumen dikirim setelah terdapat tundaan sidang dan ditutup sesuai jadwal sidang. ${ }^{17}$

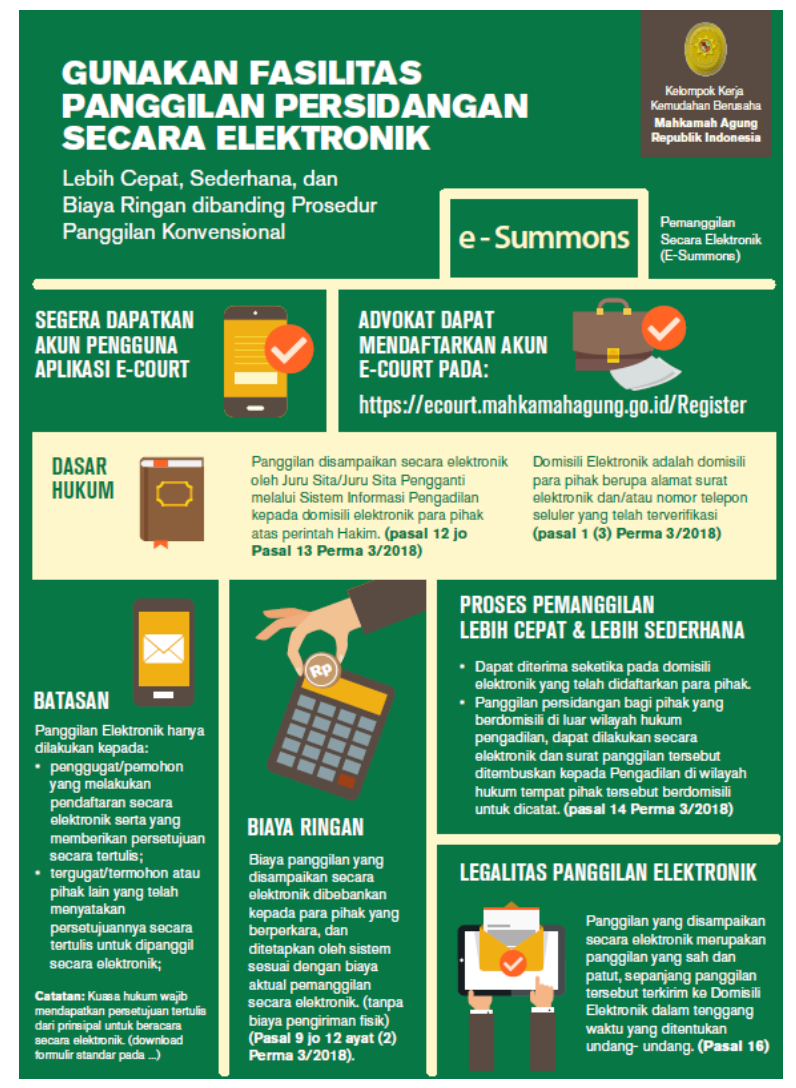

Gambar 4 : Alur Panggilan Sidang Secara Online

Mekanisme control (menerima, memeriksa, meneruskan) dari semua dokumen yang di upload para pihak dilakukan oleh majelis hakim/hakim yang berarti ketika kedua belah pihak mengirimkan dokumen dan selama belum diverifikasi oleh majelis/hakim kedua belah pihak tidak dapat melihat atau mendownload dokumen yang dikirim oleh pihak lawan. Setelah pengguna melakukan semua rangkaian pendaftaran dan persidangan secara elektronik dapat melihat ringkasan / detil perkara yang telah dilakukan. 


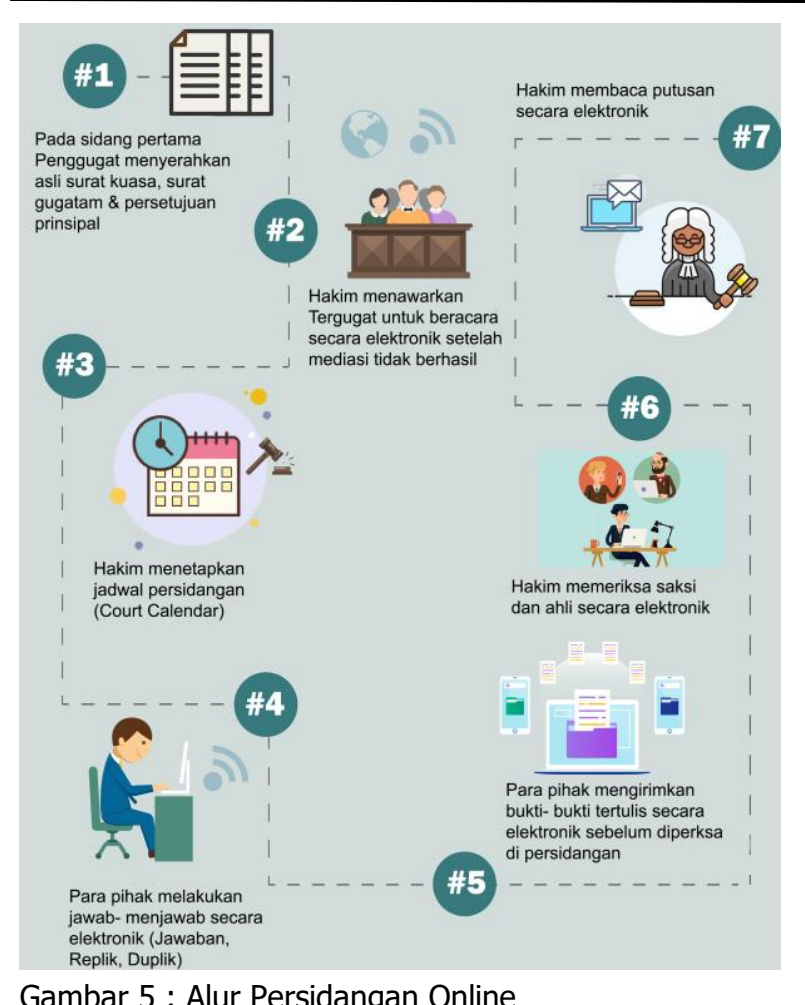

Gambar 5 : Alur Persidangan Online

Pengguna dapat memilih Nomor Perkara pada kolom Kode dan Tanggal Register dalam menu Pendaftaran Perkara. Dari Nomor Perkara yang terpilih tertera semua informasi yang terdiri dari tiga bagian yaitu Pendaftaran, Persidangan, dan Dokumen, Dalam bagian Pendaftaran terdapat informasi Pendaftaran Perkara, Pembayaran, Persetujuan Pihak Menggunakan Saluran Elektronik (persetujuan Prinsipal), Panggilan, serta Biaya Perkara. Pada bagian Dokumen berisi dokumen-dokumen yang terjadi selama persidangan antar pihak. Status dokumen dibagi menjadi dua yaitu yang terkunci dan tidak terkunci, yang tidak terkunci berarti dokumen tersebut bisa diakses atau didownload dan sudah diverifikasi oleh majelis hakim sehingga bisa dilihat oleh pihak lawan. Apabila dokumen tersebut terkunci berarti dokumen tersebut belum diverifikasi oleh majelis hakim. ${ }^{18}$

\section{Dampak terhadap advokat dalam pelaksanaan sistem e-court (electronics justice system) dalam penyelesaian perkara di Pengadilan Negeri Selong.}

Pemakaian administrasi perkara di pengadilan secara elektronik atau yang disebut dengan e-court telah memberikan dampak langsung bagi praktik advokat di Indonesia. Kemudahan yang diberikan dalam sistem teknologi canggih sistem pelayanan $e$ court menjadi sebuah kebutuhan dalam proses menyelesaikan kasus pengadilan dengan mobilitas tinggi para pihak dan para penasihat hukum (advokat). Advokat diharuskan untuk memiliki akun resmi dengan mendaftar dalam sistem e-court sehingga keberadaannya diakui secara formil. Namun, para advokat yang tidak memiliki akun e-court akan menjadi terhalang ketika membela klien di sejumlah pengadilan, hal ini sama dengan pasal 6 ayat 2 Perma Nomor III Tahun 2018 tentang Administrasi Perkara di Pengadilan Secara Elektronik yang berbunyi : Mahkamah Agung berhak untuk menolak pendaftaran pengguna terdaftar yang tidak dapat diverifikasi. Selain itu, sistem e-court juga dituangkan dalam SK Ketua Mahkamah Agung RI No.122/KMA/SK/VII/2018 Tahun 2018 tentang Pedoman Tata Kelola Pengguna Terdaftar Sistem Informasi Pengadilan dan Surat Keputusan Direktur Jenderal Badan Peradilan Umum Mahkamah Agung RI No.271/DJU/SK/PS01/4/2018 tentang Petunjuk Pelaksanaan Peraturan Mahkamah Agung No. 3 Tahun 2018 tentang Administrasi Perkara di Pengadilan Secara Elektronik. ${ }^{19}$

Atas berjalannya pelaksanaan sistem $e$ Court dalam penyelesaian perkara pada Pengadilan Negeri Selong, awalnya mengalami kesulitan, karena semuanya berawal dari cara menyampaikan kepada pihak yang berperkara terutama Advokat

19 www.repository.ut.ac.id/7957/1/ocs-2018-7.pdf (diakses tanggal 21-09-2020). 
untuk memberikan bimbingan atau pelatihan supaya dalam proses berperkara secara elektronik mempunyai pemahaman yang sama, sehingga para pencari keadilan dapat beracara dengan lancar dan meminimalisir hambatan-hambatan yang terdapat pada saat pendaftaran secara elektronik, hambatanhambatan yang dijumpai dalam proses pendaftaran oleh Advokat atau Pengguna Terdaftar adalah belum adanya pemahaman atas tampilan yang ada di dalam sistem $e$ Court itu sendiri, sehingga mendapatkan kesulitan untuk Advokat itu sendiri. Perubahan pada peradilan atas adanya eCourt tersebut adalah :

1. Adanya perubahan prosedur dalam penanganan suatu perkara, artinya bahwa mengefisiensi waktu dalam penanganan perkara.

2. Perubahan cara berinteraksi dengan aparatur Pengadilan, yang artinya bahwa para pihak yang berperkara dapat dikurangi untuk datang langsung ke Pengadilan.

3. Informasi-informasi elektronik Pengadilan dapat memudahkan masyarakat yang mencari keadilan dalam mencari informasi maupun Pengetahuan.

Adapun manfaatnya bagi Advokat adalah :

1. Penghematan waktu dan biaya dalam proses pendaftaran perkara tersebut

2. Pembayaran biaya panjar perkara dilakukan dengan virtual account yang dapat dibayarkan melalui Bank dan saluran elektronik lainnya.

3. Dokumen tersimpan dengan baik dan dapat diakses ditempat manapun berada.

Pemberlakuan teknis pendaftaran perkara dengan e-court memberikan perubahan sistem peradilan yang bersih bagi orang-orang yang menginginkan keadilan dan kepastian hukum, sehingga pelaksanaan asas peradilan cepat, sederhana dan biaya ringan. banyak masyarakat umum yang tidak mengetahui bagaimana menyelesaikan suatu perkara di pengadilan dan tentu saja memerlukan orang yang ahli dibidangnya yaitu advokat. Namun, tidak sedikit advokat yang mengalami kesulitan ketika menghadapi suatu perkara dalam membangun alibi untuk membela kliennya. Dikarenakan hukum memiliki standarisasi tertentu, maka tidak setiap fakta dalam suatu kasus dapat dijadikan sebagai fakta hukum. Data dan fakta harus dikemas, sehingga dapat utuh dan integral secara hukum. Sedikit saja terjadi kontradiksi atau tak saling menguatkan, seluruh bangunan alibi akan runtuh. Itu berarti malapetaka bagi klien dan tanggung jawab profesional (professional liability) pengacara akan dipertanyakan.

Pembelaan advokat atas kliennya lebih merupakan law battle daripada untuk mencari kebenaran, dan bukan terletak di pundak advokat untuk mencari substansi kebenaran dalam suatu perkara, ini kewajiban hakim. Oleh karena itu, tidak mengherankan apabila sudut pandang pengacara atas kebenaran dalam suatu perkara yang ditanganinya cenderung subyektif. Semua serba ditakar dari sisi kepentingan klien. ${ }^{20}$

Faktor-faktor penghambat dari penerapan e-Court yaitu sebagai salah satu sample yaitu atas nama Lalu Samsu Rizan, $\mathrm{SH}{ }^{21}$ dalam wawancara yang pada kesimpulannya mengatakan bahwa factorfaktor penghambat itu ada 2 yaitu :

a. Faktor Internal

1) Pada aplikasi e-court, saat mengupload gugatan maupun jenis surat yang lain tidak dapat di kembalikan atau diperbaiki, karena sistem telah terlebih dahulu terkunci.

${ }^{20}$ Syafrudin Makmur, Peran Advokat dalam Penegakan Hukum Ekonomi di Indonesia, Salam Jurnal Filsafat dan Budaya Hukum, Jakarta, 2014, hlm. 46

21 Lalu Samsu Rizan, Wawancara Advokat, Selong, 2020, (maret, 11.30 wita) 
2) Untuk panjar biaya perkara, terlalu seringnya menambah panjar biaya perkara, karena didalam aplikasi e-court tersebut, tidak menghitung secara maksimal, apabila terjadi pemanggilan yang berulang-ulang terhadap perkara yang didaftarkan.

b. Faktor Eksternal

1) Ada sebagian Advokat atau Pengacara yang belum mengenal teknologi informasi, dalam hal ini computer dan TI, sehingga tidak dapat mengoperasikannya secara benar dan optimal, karena dalam menjalankan aplikasi e-court tersebut harus paham dalam mengoperasikan computer dan TI.

2) Faktor usia merupakan salah satu penghamabat bagi lancarnya penggunaan e-court dan malas belajar untuk mengenal teknologi informasi

Selain faktor pernghambat secara internal dan eksternal juga adanya factorfaktor teknis yang menurut Hariadi ${ }^{22}$ selaku operator e-Court pengadilan Negeri Selong menyatakan hambataan tersebut adalah

1. Terjadinya pemadaman listrik sehingga menghabat pendaftaran $e$ court yang sedang diproses.

2. Terganggunya Jaringan Internet yang terkadang mengakibatkan proses pendaftaran terhambat.

Organisasi advokat juga menjadi salah faktor yang berkonstribusi tidak berjalanan system e-court, dikarenakan masih banyak advokat yang tidak bisa mengoperasikan komputer dan teknologi informasi. Salah satu solusi dari dampak kekurangan penerapan sistem e-court ini yaitu dengan mengadakan organisasi melakukan bimbingan teknis pendaftaran dengan cara e-court dan

${ }^{22}$ Hariadi, wawancara operator e-court PN Selong, (Juni, 2020) mengenal e-court dengan advokad, karena dalam kurun waktu per-semester atau perenam bulan, mengingat sistem e-court tersebut akan banyak fitur atau hal-hal yang baru dalam melakukan pengaksesan aplikasi oleh Pengadilan.

\section{KESIMPULAN}

Aplikasi e-court merupakan keharusan yang dijalankan bagi para Advokat untuk mendaftarkan perkaranya di peradilan tingkat pertama, sehingga memudahkan banyak hal bagi penggunanya tersebut, diantaranya adalah tanpa harus datang ke Pengadilan untuk mendaftarkan gugatannya serta keamanan data yang dapat diakses dimanapun dan kapanpun, Bagi Mahkamah Agung semangat inovasi harus dipelihara dan didukung karena sejalan dengan amanat pasal 4 ayat 2 Undang - Undang Nomor 48 Tahun 2009 tentang Kekuasaan Kehakiman bahwa pengadilan membantu pencari keadilan dan berusaha mengatasi segala hambatan dan rintangan untuk dapat tercapainya peradilan yang sederhana, cepat, dan biaya ringan.

Pengelolaan Administrasi perkara di pengadilan Negeri Selong secara elektronik atau yang disebut dengan e-court telah memberikan dampak langsung bagi praktik advokat di Indonesia. Kemudahan yang diberikan dalam sistem teknologi sistem pelayanan e-court menjadi sebuah kebutuhan dalam proses menyelesaikan perkara di pengadilan dengan mobilitas tinggi para pihak dan para penasihat hukum (advokat). Advokat diharuskan untuk memiliki akun resmi dengan mendaftar dalam sistem ecourt sehingga keberadaannya diakui secara formil.

Mahkamah Agung seharusnya meningkatkan berbagai fitur pada aplikasi eCourt yang lebih sederhana lagi, sehingga para pencari keadilan terutama Advokat dalam mengakses aplikasi tersebut dapat dengan mudah dan cepat mencari setiap informasi perkara yang sedang di tangani. 
Organisasi Advokat diharapkan memberikan fasilitas untuk anggotanya yaitu dengan mengadakannya bimbingan teknis e-Court dan pelatihan mengoperasikan computer dan mengenal teknologi informasi yang terkait dengan aplikasi e-court dan Jaringan Internet yang memadai.

\section{DAFTAR PUSTAKA}

1. Buku-Buku

Abdullah, Era Baru Peradilan Berbasis Teknologi Informasi, Starlita Dasuki (Ed), Majalah Mahkamah Agung Edisi XVII/2018.

Edi Hudiata, Modernisasi Peradilan Melalui UU KIP Nomor 14 Tahun 2008 dan SK KMA Nomor 1-144/KMA/SK/I/2011, Majalah Hukum Varia Peradilan Tahun XXVII, No.320 Juli 2012.

Mahkamah Agung RI, Cetak Biru Pembaharuan Peradilan 2010-2035, (Jakarta.2010).

Mahkamah Agung Republik Indonesia, Buku Panduan e-Court (The Electronic Justice System), Jakarta 2019, (online).(di akses tanggal 27 Maret 2020).

Rianto Adi, Metodologi Penelitian Sosial dan Hukum, Jakarta: Granit,2004.

Rita Zahara, E-court Lompatan Besar Dalam Pelayanan Perkara, Majalah Mahkamah Agung Edisi XVII/2018.

Soerjono Soekanto, Pengantar Penelitian Hukum .Jakarta: UI Press, 1986.

Soerjono Soekanto dan Sri Mamudji, Penelitian Hukum Normatif : Suatu Tinjauan Singkat, Edisi 1, Cet V, Jakarta : PT Taja Grafindo Persada , 2001.

Syafrudin Makmur, Peran Advokat dalam Penegakan Hukum Ekonomi di Indonesia, Salam Jurnal Filsafat dan Budaya Hukum, Jakarta, 2014

\section{Peraturan Perundang-Undangan}

Undang-Undang Dasar Negara Republik Indonesia Tahun 1945

Peraturan Mahkamah Agung Republik Indonesia (PERMA) Nomor 3 Tahun 2018 tentang Administrasi Perkara di Pengadilan Secara Elektronik

Peraturan Mahkamah Agung Republik Indonesia (PERMA) Nomor 1 Tahun 2019 tentang Administrasi Perkara dan Persidangan di Pengadilan secara Elektronik.

Peraturan Mahkamah Agung Republik Indonesia (PERMA) Nomor 3 Tahun 2018 tentang Administrasi Perkara di Pengadilan Secara Elektronik

\section{Peraturan Mahkamah Agung Republik Indonesia (PERMA) Nomor 1 Tahun 2019 tentang Administrasi Perkara dan Persidangan di Pengadilan secara Elektronik.}

\section{SUMBER LAIN / INTERNET}

www.repository.ut.ac.id/7957/1/ocs-2018-

7.pdf (diakses tanggal 21-09-2020). 